\title{
Study of Customer Engagement through Emotional Branding
}

\section{OPEN ACCESS}

Manuscript ID:

MGT-2021-08033455

Volume: 8

Issue: 3

Month: January

Year: 2021

P-ISSN: 2321-4643

E-ISSN: 2581-9402

Received: 08.10.2020

Accepted: 28.11.2020

Published: 01.01.2021

Citation:

Gokarna, Poojaa. "Study

of Customer Engagement through Emotional Branding." Shanlax International Journal of Management, vol. 8, no. 3, 2021, pp. 11-20.

DOI:

https://doi.org/10.34293/ management.v8i3.3455

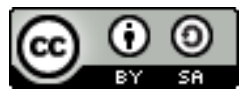

This work is licensed under a Creative Commons Attribution-ShareAlike 4.0 International License.

\section{Poojaa Gokarna}

Research Scholar, School of Business Management

Narsee Monjee Institute of Management Studies, Mumbai, Maharashtra, India iD https://orcid.org/0000-0001-9795-8845

\begin{abstract}
Purpose: This qualitative research-based study in India looks to uncover the elements that drive customer engagement towards a brand. The backdrop is a prominent use of Emotional branding as a tool for driving customer engagement. The premise of conducting this study is to identify the drivers of customer engagement, along with its implication on the marketing scenario in India.

Methodology: It is a Qualitative exploration conducted through semi-structured in-depth interviews of 32 respondents and the transcripts were analyzed to identify the major themes that convene. The themes were further used to build a conceptual framework based on the data available.

Findings: A conceptual framework has been developed revolving around the antecedents and consequences of Emotional Branding, which transmits into customer engagement. Also, obstacles to the engagement process have been discussed.

Implications: This qualitative study brought forth various constructs that give rise to customer engagement and, in turn, brand loyalty. This paper helped me understand how customers can be engaged at an emotional level and uncover a major marketing tool for brand managers. Originality: With existing researches based on quantitative methodology, the originality of this research lies in developing qualitative research for emotional branding and discussing the opportunities for customer engagement in the Indian context.
\end{abstract}

Keywords: Emotional branding, Brand attachment, Brand loyalty, Brand love, Customer engagement

\section{Introduction}

Emotional Branding today has become the new marketing mantra. There has been an evolution in consumer behavior from the more rational approach based on satisfaction from product features to developing an emotional connection or a bond with the brand. Consumers are no longer interested in the commodity that satisfies their needs, but in the brand that depicts their image and knows how the brand makes them feel, thereby creating an attachment. Marc Gobe' coined the term emotional branding. Emotions, as defined by Descartes, are 'Series of automatisms and human behavior different than the cognitive process.' According to Darwin, 'Emotions are adaptive and help in communication.' It is a mental state that arises when exposed to a certain event, thought, or process and can be synonymous with feelings. Emotions are utilized today to influence the consumer's response to a product. Most successful organizations today seem to engage with consumers by having a dialogue with them at emotional level that resonates with their intrinsic needs.

Brands, too, have transitioned from using traditional benefit-based advertising strategies to emotional appeal-based advertising for developing a long-term connection with the consumers. In an era where product differentiation is reducing, the only differentiation created is by giving the brand a personality. Many top companies, nationally \& internationally, have adopted the emotional advertising route. 
Through their advertising, these companies reflect upon local culture, traditions, or personalities integral to the individual who can be depicted through the brand. Numerous examples of the same can be cited which are in the Indian context.

1. Google Search Reunion Campaign: Google is an international company. But these ad campaigns focus on the emotions set amidst the friendship of two senior citizens, one based in India and the other in Pakistan. It clearly shows how the search engine helps bring together the two lost friends. Thus, it focuses on the emotions of love, longing and friendship. (https://www. youtube.com/watch?v=T9Ikr-OrBFk)

2. Khulkekhelo campaign by Parachute: This ad hardly talks about the hair oil or its benefits. It is based in a nursing home. The ad shows the inmates of the nursing home playing "Khulke" with the colors. This ad encourages people to strengthen the bonds of relationship and love, another emotional aspect. (https://www.youtube. $\mathrm{com} /$ watch? $\mathrm{v}=\mathrm{s} 3 \mathrm{w}-\mathrm{Dt6mAWo}$ )

3. Dabur Vatika Campaign: Their campaign salutes the female cancer survivors. This ad shows a cancer survivor woman, ready to redeem her life. However, she is hesitant. It depicts the lovely relationship between the husband and wife and how the husband helps his wife resume her confidence and move on with life. (https://www. youtube.com/watch? $\mathrm{v}=$ QomoNyfkqvg)

4. Tanishq Remarriage Campaign: Many of the ad campaigns from the TATA Group have been based on the emotional aspects. Be it the Jaago Re campaign of TATA Tea or the recent ad campaign of Tanishq, which shows a woman getting remarried and how her would-be husband builds a relationship with her daughter from a previous marriage trust and love. The same emotions that the TATA brand stands for. (https:// www.youtube.com/watch?v=P76E6b7SQs8)

5. Johnson \& Johnson Campaign: Their ad campaigns are predominantly emotional, which depicts unconditional love between a mother \& child. It banks on emotions of love and attachment. Thus, they have garnered a strong attachment between brand and the customers. (https://www. youtube.com/watch?v=XNFQ0n0YR-Y)

\section{Mountain Dew 'Dar keaage jeet hai'} Campaign: This again talks about the emotion of fear. If one conquers the emotion of fear, one will emerge victoriously. This personality trait that many individuals possess and how the brand internalizes the same and proposes people to overcome their fear. (https://www.youtube.com/ watch? $\mathrm{v}=\mathrm{S} 1 \mathrm{Dj} 4 \mathrm{WwRzXw}$ )

These ad campaigns become the driving force for the brands to put across the various emotional aspects to the consumers. They create an emotional bond with the client, which is strengthened when the consumer experiences the brand. This creates trust and loyalty, thereby engaging consumers.

Consumers today make decisions emotionally and rationalize them logically, which was supported by (Morrison \& Crane 2007), mentioning that emotions do facilitate decision making when logic and information are unavailable. (Dewitt et al. 2008) suggested that emotional branding is a facilitator of brand loyalty. Both the marketing practitioners and the academic fraternity are keen to understand the consumers' emotional attachment to the brand, which gives the firms a competitive advantage and a high level of performance (Malar et al., 2011). Consumers develop a strong emotional connection with the brand. This attachment theory helps predict how an individual interacts with the brand (Bowlby 1979). This emotional connection or bond between the consumer and the brand may urge the consumers to make financial sacrifices to maintain proximity with it. (Thompson et al., 2005) coined the term emotional brand attachment, which is conceptually similar to brand love elaborated by (Roberts, 2004) in his book Lovemarks. (Batra et al., 2012) suggested that consumers do form an emotional relationship with the brand, which is very strong. They find the brand irreplaceable and experience anxiety about their withdrawal.

\section{Literature Review}

Malar et al., (2011) studied emotional branding by examining the relationship between the type of selfcongruence and emotional brand attachment through mediators like product involvement, self-esteem, and public self-consciousness. Results indicate that there is a relatively stronger effect of self-congruence on 
emotional brand attachment. This study does not extend the said attachment between the brand and the consumer any further.

Park et al., (2010) examined the relationship between "brand attachment" and their interpretation of attitude strength and claim empirical evidence for discriminant validity between the two. The result proposes attachment predicts actual behavior better than brand attitude strength. Thus, this validates that emotional branding is essential for consumer engagement.

Park et al., (2006) focus on how attitudes affect the brand relationship and the behaviors consumers share with the brands. The potential difference between the two constructs, brand attitude and attachment, are elucidated. The results show that extreme brand attitudes form strong relationships with consumers, thereby creating commitment from the consumer side. Thus, the consumers may exhibitready acceptance of extensions to high-attachment brands.

Carroll and Ahuvia (2006). The author here has tested a new construct - brand love. The results suggest that brand love is a meaningful mode of consumer satisfaction linked to desirable postconsumption behavior. Self-Expressive brands tend to be more loved. Managers may find that enhancing these aspects of their offerings increases emotional response in consumers.

Loureiro et al., (2012) aim to integrate brand attachment as an antecedent of brand love and commitment and brand trust as mediators between brand trust and loyalty. The results suggest that Brand attachment has a significant positive effect on brand love feeling. The feeling of love toward a brand can reinforce trust, the interest in continuing the relationship and faith in the future regarding the brand.

Patwardhan and Balasubramanian (2011) seek to understand the constructs of brand romance connected to brand loyalty and provide a complementary perspective on emotional attachment to the brand. The author proposes that emotional attachment from attraction generates the three dimensions of the brand romance construct - pleasure, arousal and dominance. The results state that brand romance creates brand attraction and is different from the construct brand attitude.

Hwang and Kandampully (2012) aim to investigate the roles of three emotional factors, namely selfconcept connection, emotional attachment and brand love, concerning young consumer- luxury brand relationships. This research demonstrates that younger consumers' emotional aspects (self-concept connection, emotional attachment, and brand love) improve their brand loyalty. Among the three, emotional attachment has the strongest impact on brand loyalty.

Hung, H.Y. (2014) proposes that there are two mediating mechanisms that explain internalization and socialization dynamics: need fulfillment with brand attachment, and supporting values with community identification, respectively. The results show that brand self-congruence acts as an internalizing mechanism in the brand attachment process. Furthermore, the similarity of perceptions among the brand, community, and other members (fully) mediates the relationship between brand attachment and community identification.

Thomson et al., (2005) propose to develop a scale to measure the strength of consumers' emotional attachments to brands. That study also examines the scale's predictive validity, showing that it is positively associated with indicators of both commitment and investment.

Pandey (2006) mentions that consumers selectively acquire information. The extent of emotions of the consumer diversifies the emotional purchases of the consumers. The tool used by marketers to deliberately touch the emotions of the consumers is emotional advertisements. These advertisements acquire a favorable response of the consumers towards the product. Therefore, it has been concluded that the marketers of a particular product or brand make use of the emotional advertisement technique as a stimulant in changing or forming the attitude of the potential consumers. Thus, one strong tool that can be used by the consumers is their emotions and it is mostly adapted by the marketers as a strategic initiative for making the brand successful in the market.

According to Jamwal and Soodan (2014), the mentality of human beings is such that they are instinctively determined to be highly uncomfortable 
while facing conflicts in the information they usually believed. They are claimed to have a general propensity to shift between psychological states or emotions. The marketers make use of this human tendency to make their consumers get shifted to a particular brand. The frontline tool used by most marketers is emotional branding, and it naturally touches the emotional chords of the consumers, creating a connection between their purchase decisions and a particular brand. The emotional branding strategy is mostly adopted by competitive brands to build an emotional connection with the hearts of the consumers. This widely used strategy is claimed to chiefly focus not on the product but only on the consumers.

Chamberlain and Broderick (2007), in their research, examined the emotions of the consumers and social science measures that can be used to incarcerate the emotional experience of the consumers. The analyses inferred that the marketers probably place emotional signs in brand designs, advertisements, and packages designed to generate emotional responses. Some of the consumers are also claimed to be aware of the marketing strategies adapted by marketers. Thus, the measurement of psychological indicators for evaluating the emotions investigated the behaviors of the consumers and marketers.

Chaudhuri \& Holbrook (2001) Here, the authors examine two aspects of brand loyalty, purchase loyalty, and attitudinal loyalty: linking variables in the chain of effects from brand trust and brand affect to brand performance (market share and relative price). The results indicate that when the productand brand level variables are controlled for, brand trust and brand effect combine to determine purchase loyalty and attitudinal loyalty. Purchase loyalty, in turn, leads to greater market share, and attitudinal loyalty leads to a higher relative price for the brand.

Yoo\& McInnis (2005) mentions that the leveraging force between the consumers and the brands are the emotions. It leads to brand attitude formation. The emotions help consumers garner the required experience, thereby integrating the brands in their lives. They further explained that, as opposed to the conventional benefit-driven branding approach, emotional branding focuses on brand meanings that interact with consumer lives and inspire their passion, life stories, memories, and experiences.

The above studies discuss emotions with brands concerning different antecedents and consequences. Also, Bowlby (1979) and Hazan \& Shaver (1987) has maintained in the Attachment theory that dynamic long term or short-term attachments are established with the caregiver. The study is adapted to brands to state that attachments with the brands give rise to loyalty, which in turn increases the brand profitability. Another theory by Deci \& Ryan (2000), called the Self-determination theory, states that satisfaction of the autonomy, relatedness, and competence (ARC) need plays a critical role in predicting feelings and fostering attachments. Taking a cue from the mentioned theories and the literature review, we gather that a lot has been explored about emotional branding, thereby creating brand attachment, brand loyalty, and trust. However, there is a need to study the impact of emotional branding in creating an engaging relationship with the consumer using a qualitative methodology to bring forth new variables.

\section{Research Methodology}

To tackle the research question, qualitative research was utilized because it helps in understanding the meaning people assign to social phenomena and to elucidate the mental processes underlying their behaviors (Weinreich, 1996). Semi-structured indepth interviews of 32 respondents were conducted. It also provided scope for further investigation of relevant factors that may not explicitly come out through the literature review. The average duration of each interview was around thirty-five minutes. For this study, the emotional brand attachment of a respondent was studied in any product category which he/she likes and finds it difficult to substitute. The respondents were asked about an advertisement that creates positive emotions in their minds and its relation to the brand. The reasons for such an emotional connection and love for the brand were also elucidated. Also, they were asked what they could do to maintain this relationship with the brand. The reasons for the loss of their faith in the brands in some cases were found out. The data was collected in an urban setting with the age group of the respondents 
being $18-35$ years. Of the respondents, $43.75 \%$ were females and $56.25 \%$ were males. A youthful category of respondents was considered more appropriate for this topic based on brand-consumer engagement. But this also led to the representation of a certain category of brands as compared to the others. When depicting the excerpts from the interview in this paper, ' $R$ ' signifies Respondent and the number is the serial number. ' $M$ ' or ' $F$ ' signifies the gender, male or female.

\section{Analysis \& Development of Conceptual Map}

The analysis helped in confirming the constructs identified through the literature review. It also helped in elaborating two new constructs and also identifying the obstacles in the process of customer engagement.

\section{Emotional Branding}

Emotions are a mental state of readiness that arises from the appraisal of events of one's thought (Bagozzi et al., 1999). Emotions are elicited during advertisement exposure. Exposure stimulates constant information processing, including affective response to the ad, which influences brand attitude formation (Holbrook \& Batra., 1987). Those advertisements which depict positive brand emotions are valued more favorably and influence the belief about the brand, thus creating a brand attitude. The brand is evaluated based on promised emotional benefits. These intense psychological bonds with the brands referred to as emotional brand connections lead to higher levels of firm performance and competitive advantage (Malar et al., 2011). The emotional linkages between consumers and the brand result in increased commitment (Grisaffe and Nguyen, forthcoming), customer satisfaction (Bagozzi et al., 1999), loyalty, and repurchase intention. Gobe 2001 reflects emotional branding to create a personal dialogue with the consumers, which adds credibility through powerful connections on a personal and holistic level (Jawahar and Maheswari, 2009).

Respondents were aware of the emotions they experienced when watching the advertisements of their loved brands. They tickled their senses and touched their hearts.
Every time the Dairy Milk rakhi commercial comes on TV, I remember how I used to share the chocolate with my brother. It's nostalgic. (R $17, F)$

The Raymonds "Complete Man" ads. They are just so elegant. Every time you see the ad, you simply want to fall in love. (R 11, F)

Respondents were also aware of the attitude that they formed about a brand on watching an advertisement.

All the Titan Watch commercials are so unique. They just bring out good things about the idea of gifting. ( $R$ 7, M)

I just loved the new Google Ad. It has such positive emotions around friendship. (R 2, F)

Respondent narrated brands where they saw a self-reflection or personification of themselves within the brand.

Royal Enfield. It is very macho. Very me. I want to explore new places riding on it. $(R, M)$

I adore the Johnson ads. It just feels like yesterday when I used these products on my son. All the motherly love comes up. (R 3, F)

All these themes coming up through the interviews were collated together to form a theme, Emotional brand experience.

\section{Brand Attachment}

Attachment theory was given by Bowlby (1982), which gave the relationship between an infant and its caregiver. Humans also form these emotional bonds with companies and brands (Carol \&Ahuvia., 2006; Park \& MacInnis, 2006). A simple definition of brand attachment can be an emotional-laden bond or an emotional link between a person and a brand. (Thomson et al., 2005). Consumers get emotionally attached to a few brands and display connection, passion, and affection towards them (Thomson et al., 2005). Park et al. (2006) defined brand attachment as "the strength of the cognitive and emotional bond connecting the brand with the self."

Respondents discussed a bond with the product brand that they utilized, which were inseparable.

My morning does not start without a cup of Nescafe. I feel incomplete without my cuppa. (R 15, M)

Colgate is like a family member. My parents used it, I use it and now I trust it for my children. (R 12, F) 
Parle $G$ brings childhood memories. The feeling of dipping it in your chai and having it is just great! ( $R$ 5, M)

Respondents also spoke about a community feeling of attachment when they consumed some brands.

We started hanging out at Love \& Latte from our college days. Initially, our visits were occasional. Then it became a weekend affair. Now we just look at opportunities to be there. It is a great place to hang out with friends. (R 9, M)

I use TATA Tea. I feel connected to their Jaago Re campaign. Whenever possible, I do my bit towards society. (R 27, F)

I use Forest Essentials. I like the product. But I love the fact that they are committed to green marketing, the welfare of society and Ayurveda. (R 30, F)

Like Emotional branding, all the themes emerging were collected and merged to form a bigger theme called brand attachment.

\section{Brand Love}

Ahuvia (1993, 2005a, 2005b) initiated empirical research looking in detail at consumers' ability to love products and consumption activities. Using an interpretive paradigm, Ahuvia found that many consumers have intense emotional attachments to some "love objects," which he defined broadly as anything other than another person. Carol \& Ahuvia (2006) defined brand love as a passionate and emotional feeling for a trading name. It is pure, emotional and a mix of rational and irrational behavior, where the rational part is the cognitive thinking and evaluation. Brand love includes attachment for the brand, passion for the brand, positive evaluation of the brand, positive emotions in response to the brand and declaration of love for the brand. Love smitten individuals provide money, time, efforts and resources for nurturing their relationship. Consumers and brands are treated as relational partners in the dyadic relation. Those in love with their brand are expected to perform voluntary behaviors such as providing favorable feedback, positive WOM and so on Aaker (1991).

Respondent began to share the love like feeling they experience for the brand. It starts with a liking for the brand through the various stimuli, which later intensify using the product. The experience and the fulfillment of the need create a strong feeling.

I absolutely love my Sony PlayStation. It is so up to date and the technology is far superior to its competitors. (R 21, M)

Whenever I am feeling low or depressed, I look for Dairy Milk Chocolate. It is a pure pleasure. It is like therapy. (R 14, F)

A pack of Maggi Noodles was our savior for latenight studies during college days. I have tried other products, but none could come near Maggi. Now I am a die-hard fan. (R 17, M)

I have traveled almost half of India with Kesari Tours. It feels at home when I travel with them. Their service is great, and the people are friendly. When I want to book a tour, the only name that comes to my mind is Kesari. (R 13, M)

I like eating with my family at Samrat Hotel. The ambiance and food quality are great. What I love is the warmth of the people serving your food. They are sincere in their approach. I travel all the way just to eat there. $(R 18, M)$

All the themes revolving around the love for the product brand were clubbed to form the construct of brand love.

\section{Customer Engagement}

It is about encouraging your customers to interact and share their experiences with the brands with others. It could be through positive word of mouth or through sharing positive experiences. It ensures value creation for the brand in the long run. It is the strongest indicator of customer feelings about your brand. It is a worthy goal for any brand which ensures long term association with the customer.

Respondents mentioned that they recommended their loved brands to friends and family.

I recommend my friends to buy Maruti Cars only. The cars a good and they're after service is also great. ( $R$ 29, M)

I look for new products from the L'oreal brand. When my friend asked me which cosmetic products are good for the Indian skin type, I immediately recommended L'oreal. (R 10, F).

I just can't stop talking about my new iPhone 7. The features are so good and very simple to use. It is worth the price. (R 23, M)

Respondents also mentioned the extent to which they could go to maintain proximity with the brand they love.

I like the parlor treatments at Lakme Salon. I travel for 
more than half an hour to go to Lakme because I like the service. ( $R 23, F)$

I like the fit of Levi straight fit jeans. It makes me feel confident and comfortable. I make it a point to buy only Levi's even if they are a little expensive. (R 24, M) Nowadays, I am addicted to Baskin Robin icecream. It has become a nightly ritual to eat an ice-cream after dinner. I take a detour while returning from the office to buy a take home. $(R 16, F)$

\section{Brand Loyalty}

Park et al., (2005) indicated that consumers tend to display loyalty behaviors when an attachment is strong because consumers possess salient thoughts and feelings about the brand since it is integral to their self. It can be defined as the customer's preference for a particular brand over the others in a product category. It occurs when there is a long attachment or bond created between the product and the customer. It may result in repeat purchases. Aaker (1991) defines brand loyalty as a measure of attachment that a consumer has towards a brand. Brand loyalty, according to him, is how likely the consumer will switch brands because of price or product features. Thus, according to him, the core of a brand's equity lies in customer loyalty.
Respondents mentioned that whatever the competition, they have been sticking with the brand they consume for several reasons.

I have been using Dove Soap for many years now. I don't see any other soap replacing it. I have found the right match for my skin. $(R 8, F)$

Pizza Hut is my favorite place for Pizza. The taste and ambiance are so good that I have never thought of trying at any other pizza outlet. (R 19, M)

I am a loyal customer of the LIC of India. I trust them, so did my parents. I haven't invested in any other life insurance provider. (R 20, M)

\section{Obstacles to Engagement}

Obstacles are situation influences that may be caused because of several reasons. It affects loyalty and repurchase intentions. The type of obstacles may vary across geographies and economies.

I currently ride a Pulsar. I like my current bike, but I aspire to buy a Royal Enfield. I love that brand. The price being very high, I can't buy it. (R 21, M)

I was a regular user of the Patanjali brand of products. But, after a while, I found that it was not up to the mark. It let me down on the quality aspect. (R 32, M)

Based on the findings of this study, a conceptual framework was prepared. The framework shows the relationships between the different constructs discussed in the research.

\section{Conceptual Framework}

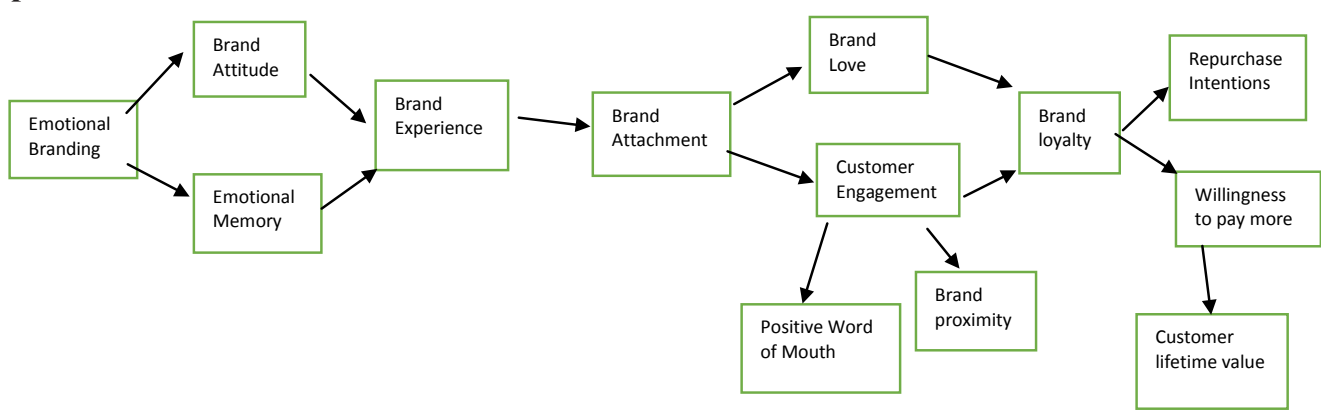

\section{Marketing Implications \& Scope for Further Study}

This study is aimed at understanding the drivers of emotional branding and how it affects customer engagement - this qualitative study brought forth various constructs that give rise to customer engagement and, in turn, brand loyalty.
The advertisements and the brands discussed in this paper were representing the Indian context. More and more brands today are engaging themselves with the customers at the emotional level. This paper supports this proposition and elicits that brand attachment at an emotional level gives rise to engagement, which creates a sustainable value proposition for the 
brand's future. The study reveals that an engaged consumer will create positive word of mouth for the brand and has great repurchase intentions and a willingness to pay more. They also go to any extent to maintain the proximity to the brand. Indian brands are increasingly using the emotional mode to connect with the consumers. The key question here is how the merely liked brand is converted to a loved brand. The advertisements listed earlier in the paper create an emotional bond with the consumer. Even if it is ideal that the consumer and the brands are connected at an emotional level and the decisions with the same are generally irrational, the brands must live up to the consumer's expectations. The feeling and emotions after the brand experience should only be heightened. Any obstacle intervening in this process should be avoided.

Further research can be conducted regarding the obstacles in customer engagement and identify its implications on overall brand image and brand loyalty. Also, this research is based on urban settings in the Indian scenario. It can also be extended to rural context and customer engagement for international brands in Indian settings. Both qualitative and quantitative studies can be utilized to study the same.

\section{References}

Aaker, David A. Managing Brand Equity: Capitalizing on the Value of a Brand Name, Free Press, 2000.

Abosag, Ibrahim, et al. "Examining the Relationship between Brand Emotion and Brand Extension among Supporters of Professional Football Clubs." European Journal of Marketing, vol. 46, no. 9, 2010, pp. 1233-1251.

Ahuvia, Aaron C. I love it! towards a Unifying Theory of Love across Diverse Love Objects, 1993.

Ahuvia, Aaron C. The Love Prototype Revisited: A Qualitative Exploration of Contemporary Folk Psychology, 2005.

Ahuvia, Aaron, et al. "Brand Love: Towards an Integrative Model." Advances in Consumer Research, vol. 35, 2008, pp. 176-180.

Ahuvia, Aaron C. "Beyond the Extended Self: Loved Objects and Consumers Identity Narratives." Journal of Consumer Research, vol. 32, no. 1, 2005, pp. 171-184.
Assiouras, Ioannis, et al. "The Impact of Brand Authenticity on Brand Attachment in the Food Industry." British Food Journal, vol 117, no. 2, 2014, pp. 538-552.

Bagozzi, Richard P., et al. "The Role of Emotions in Marketing." Journal of the Academy of Marketing Science, 1999, pp. 184-206.

Batra, Rajeev, et al. "Brand love." Journal of Marketing, vol. 76, no. 2, 2012, pp. 1-16.

Bowlby, John. Attachment and Loss, Tavistock Institute of Human Relations, 1982.

Bowlby, John. The Making \& Breaking of Affectional Brands, Tavistock, 1979.

Breward, Christopher. The Culture of Fashion: A New History of Fashionable Dress, Manchester University Press, 1995.

Carroll, Barbara A., and Aaron C. Ahuvia. "Some Antecedents and Outcomes of Brand Love." Marketing Letters, vol. 17, 2006, pp. 79-89.

Chamberlain, Laura, and Amanda J. Broderick. "The Application of Physiological Observation Methods to Emotion Research." Qualitative Market Research: An International Journal, vol. 10, no. 2, 2007, pp. 199-216.

Chaudhuri, Arjun, and Morris B. Holbrook. "The Chain of Effects from Brand Trust and Brand Affect to Brand Performance: The Role of Brand Loyalty." Journal of Marketing, vol. 65,2001 , pp. 81-93.

Darwin, Charles. The Expression of the Emotions in Man and Animals, John Murray, 1872.

Deci, Edward L., and Richard M. Ryan. "The 'What' and 'Why' of Goal Pursuits: Human Needs and the Self-Determination of Behavior." Psychological Inquiry, vol. 11, no. 4, 2000, pp. 227-268.

Descartes, Rene. The Passions of the Soul, translated by Stephen Voss, Hackett Publishing Company, 1989.

DeWitt, Tom, et al. "Exploring Customer Loyalty Following Service Recovery: The Mediating Effects of Trust and Emotions." Journal of Service Research, vol. 10, 2008, pp. 269-281.

Dunn, Lea, and JoAndrea Hoegg. "The Impact of Fear on Emotional Brand Attachment." Journal of Consumer Research, vol. 41, no. 1, 2014, pp. 152-168. 
Fournier, Susan. "Consumers and their Brands: Developing Relationship Theory in Consumer Research." Journal of Consumer Research, vol. 24, no. 4, 1998, pp. 343-373.

Gobe, Marc. Emotional Branding: The New Paradigm for Connecting Brands to People, Allworth Press, 2010.

Grisaffe, Douglas B., and Hieu P. Nguyen. "Antecedents of Emotional Attachment to Brands." Journal of Business Research, vol. 64, no. 10, 2011, pp. 1052-1059.

Hamann, Danilo, et al. "Branding Strategy and Consumer High-Technology Product." Journal of Product \& Brand Management, vol. 16, no. 2, 2007, pp. 98-111.

Hazan, C. and Shaver, Phillip. "Romantic Love Conceptualized as an Attachment Process." Journal of Personality and Social Psychology, vol. 52, no. 3, 1987, pp. 511-524.

Hirschman, Elizabeth C., and Morris B. Holbrook. "Hedonic Consumptions: Emerging Concepts, Methods \& Propositions." Journal of Marketing, vol. 46, no. 3, 1982, pp. 92-101.

Holbrook, Morris B., and Elizabeth C. Hirschman. "The Experiential Aspects of Consumption: Consumer Fantasies, Feelings, and Fun." Journal of Consumer Research, vol. 9, no. 2, 1982, pp. 132-140.

Holbrook, Morris B., and Rajeev Batra. "Assessing the Role of Emotions as Mediators of Consumer Responses to Advertising." The Journal of Consumer Research, vol. 14, no. 3, 1987, pp. 404-420.

Hung, Hsiu-Yu. "Attachment, Identification, and Loyalty: Examining Mediating Mechanisms across Brand and Brand Community Contexts." Journal of Brand Management, vol. 21, 2014, pp. 594-614.

Hwang, Jiyoung, and Jay Kandampully. "The Role of Emotional Aspects in Younger Consumerbrand Relationships." Journal of Product \& Brand Management, vol. 21, no. 2, 2012, pp. 98-108.

Jamwal, Mohit, and Vishal Soodan. "Emotional Branding as a tool for Dissonance Reduction: A Strategy for Competitive Advantage." International Monthly Refereed Journal of
Research in Management \& Technology, vol. 3, 2014, pp. 25-32.

Jawahar, P. David, and R. Maheswari. "Service Perception: Emotional Attachment as a Mediator of the Relationship Between Service Performance and Emotional Brand." IUP Journal of Marketing Management, 2009.

Joji, Alex, N., and Ashwin Joseph. "Hedonic Versus Utilitarian Values: The Relative Importance of Real and Ideal Self to Brand Personality and Its Influence on Emotional Brand Attachment." XIMB Journal of Management, vol. 9, no. 2, 2012, pp. 77-90.

Loureiro, Sandra Maria Correia, et al. "Brand Emotional Connection and Loyalty." Journal of Brand Management, vol. 20, 2012, pp. 13-27.

Malar, Lucia, et al. "Emotional Brand Attachment and Brand Personality: The Relative Importance of the Actual and the Ideal Self." Journal of Marketing, vol. 75, no. 4, 2011, pp. 35-52.

Morrison, Sharon, and Frederick G Crane. "Building the Service Brand by Creating and Managing an Emotional Brand Experience." Journal of Brand Management, vol. 14, 2007, pp. 410-421.

Pandey, Akhilesh Chandra. "Strategic Imperatives in Emotional Branding." Gumbad Business Review, vol. 2, no. 1, 2006, pp. 110-115.

Park, C.Whan, and Deborah J. Macinnis. "What's In and What's Out: Questions on the Boundaries of the Attitude Construct." Journal of Consumer Research, vol. 33, no. 1, 2006, pp. 16-18.

Park, C. Whan, et al. "Brand Attachment and Brand Attitude Strength: Conceptual and Empirical Differentiation of Two Critical Brand Equity Drivers." Journal of Marketing, vol. 74, no. 6, 2010, pp. 1-17.

Patwardhan, H. and Siva K. Balasubramanian. "Brand Romance: A Complementary Approach to Explain Emotional Attachment towards Brands." Journal of Product \& Brand Management, vol. 20, 2011, pp. 297-308.

Roberts, Kevin. Lovemarks: The Future Beyond Brands, Powerhouse Books, 2005. 
International Journal of Management

Schouten, John W., and James H. McAlexander. Weinreich, Nedra Kline. "A More Perfect Union:

"Subcultures of Consumption: An

Ethnography of the New Bikers." Journal of Consumer Research, vol. 22, 1995, pp. 43-61.

Thomson, Matthew, et al. "The Ties that Bind:

Measuring the Strength of Consumers'

Emotional Attachments to Brands." Journal

of Consumer Psychology, vol. 15, no. 1, 2005, pp. 77-91.

Vlachos, Pavlos A., et al. "Consumer Retailer Emotional Attachment - Some Antecedents and the Moderating Role of Attachment Anxiety." European Journal of Marketing, vol. 44, no. 9/10, 2010, pp. 1478-1499. Integrating Quantitative and Qualitative Methods in Social Marketing Research." Social Marketing Quarterly, vol. 3, no. 1, 1996, pp. 53-58.

Yoo, Changjo, and Deborah MacInnis. "The Brand Attitude Formation Process of Emotional and Informational Ads." Journal of Business Research, vol. 58, 2005, pp. 1397-1406.

Zhou, Zhimin, et al. "How do Brand Communities Generate Brand Relationships? Intermediate Mechanisms." Journal of Business Research, vol. 65 , no. 7, 2012, pp. 890-895.

\section{Author Details}

Poojaa Gokarna, Research Scholar, School of Business Management, Narsee Monjee Institute of Management Studies, Mumbai, Maharashtra, India, Email ID: poojaagokarna@gmail.com 